\title{
Risiko Stunting pada Pasien Diabetes Mellitus
}

\author{
Emy Rianti \\ Program Studi Kebidanan, Politeknik Kesehatan Kemenkes Jakarta I \\ Email: emyrianti@gmail.com
}

\begin{abstract}
Risk of Stunting in Diabetes Mellitus Patients. In the last decade, more evidence that malnutrition at a very early age and occurs chronically or recurrently is an important risk of non-communicable diseases in adulthood, and one of them is diabetes mellitus. In addition, studies on the pattern of linear growth in Indonesia suggest that growth failure brings consequences of retained effects in later ages. Growth failure in infants and children is a benchmark for future short-term growth failure in adulthood. The objective of the study was to assess the factors that became the risk of adult stunting in patients with diabetes mellitus. The type of this research was quantitative with the analytic method through cross-sectional study design approach, involving 60 respondents, data were taken in Depok General Hospital of West Java, on September 2016, data taken in primary and secondary. Criteria for patients with diabetes mellitus were determined based on doctor's diagnosis, while weight, height, and economic status data were obtained through direct interview and measurement. Stunting was determined by WHO standards in 2006 and BMI was determined according to WHO standards in 2004. The results of this study indicate that there was a significant relationship between age with short-term patients with diabetes mellitus. A recommendation, need further research with a more controlled design to ensure the long-term impact of risk of non-communicable diseases as a response to malnutrition at an early age.
\end{abstract}

Keywords: Stunting, Diabetes Mellitus

\begin{abstract}
Abstrak: Risiko Stunting pada Pasien Diabetes Mellitus. Dalam dekade terakhir ini, semakin banyak bukti bahwa kurang gizi pada usia sangat dinidan terjadi secara khronis atau berulangmerupakan risiko penting terhadap terjadinya penyakit tidak menular di usia dewasa, dan salah satunya adalah penyakit diabetes mellitus. Selain itu, berbagai studi pola pertumbuhan linier di Indonesia menunjukkan bahwa kegagalan pertumbuhan membawa konsekuensi adanya retained effect di usia selanjutnya.Kegagalan pertumbuhan saat bayi dan anak-anak merupakan tolak ukur terjadinya kegagalan pertumbuhan dimasa datang seperti pendek di usia dewasa. Tujuan penelitian adalah untuk menilai faktor yang menjadi risiko status pendek (stunting) usia dewasa pada pasien dengan diabetes mellitus. Jenis penelitian ini adalah kuantitatif dengan metode analitik melalui pendekatan desain studi kroseksional, melibatkan 60 responden, pengambilan data pada bulan September 2016 di RSUD Depok Jawa Barat, data diambil secara primer dan sekunder. Kriteria pasien diabetes mellitus ditentukan berdasarkan diagnosa dokter, sedangkan data berat badan, tinggi badan dan status ekonomi diperoleh melalui wawancara langsung dan pengukuran. Stunting ditentukan berdasarkan standar WHO tahun 2006 dan IMT ditentukan berdasarkan standar WHO tahun 2004. Hasil penelitian menunjukkan bahwa ada hubungan yang signifikan antara umur dengan stunting pada pasien diabetes mellitus. Rekomendasi, perlu penelitian lebih lanjut dengan desain yang lebih terkontrol untuk memastikan dampak jangka panjangrisiko terjadinya berbagai penyakit tidak menular sebagai respon kekurangan gizi pada usia dini.
\end{abstract}

Kata kunci: Stunting , Diabetes Mellitus

\begin{abstract}
Diabetes mellitus menggambarkan gangguan metabolik yang disebabkan ketidakmampuan tubuh untuk memanfaatkan insulin, yang ditandai oleh hiperglikemia kronis dan gangguan metabolisme karbohidrat, lemak serta protein. Gangguan metabolisme yang terjadi disebabkan karena adanya kerusakan sel beta pankreas yang menyebabkan kekurangan insulin dan atau adanya resistensi terhadap aksi insulin. Efek diabetes mellitus mencakup kerusakan, disfungsi dan kegagalan berbagai organ. Kadar gula darah yang tidak terkontrol pada penderita
\end{abstract}

diabetes mellitus dapat merusak jantung, pembuluh darah, mata, ginjal, dan saraf (WHO, 2011).

Selama ini penyakit diabetes mellitus banyak dikaitkan dengan perubahan pola hidup, sosial ekonomi dan faktor keturunan. Akan tetapi dalam tiga dekade terakhir ini bukti semakin banyak dan meyakinkan bahwa kurang gizi yang terjadi pada usia sangat dini dan yang terjadi secara khronis dan/atau berulang merupakan risiko penting terhadap terjadinya berbagai penyakit kronis atau penyakit tidak menulardi usia 
dewasa termasuk penyakit diabetes mellitus, penyakit jantung dan hipertensi (Mulyantoro, 2013).

Beberapa penelitian memberikan hasil bahwa janin dalam masa perkembangannya mempunyai plastisitas yang tinggi dalam merespon lingkungan yang kekurangan gizi, artinya perkembangan janin akan mengalami penyesuaian terhadap lingkungan tersebut antara lain dengan mengurangi jumlah sel, sehingga sebagian organ mempunyai ukuran yang lebih kecil dari seharusnya (Barker, 2008). Perubahan bersifat permanen, sehingga bayi saat lahir akan mempunyai lingkungan gizi yang relatif berlebihan. Dalam jangka panjang, yaitu pada masa dewasa, akan meningkatkan risiko terjadinya berbagai penyakit tidak menular.

Faktor risiko ini terjadi karena periode janin merupakan saat mulai dibentuk berbagai organ tubuh, pematangan fungsi organ, percepatan panjang dan besarnya tubuh (Brown, 2011). Periode ini merupakan periode kritis dimana pengaruh buruk lingkungan terutama kekurangan gizi akan memberikan efek negatif ketidaksempurnaan struktur dan fungsi organ yang bersifat irreversible. Maka pencegahan terjadi kekurangan gizi pada masa ini memberikan peluang yang sangat tinggi untuk mencegah terjadinya berbagai akibat di masa dewasa termasuk risiko terjadinya penyakit diabetes. Oleh karena itu periode ini disebut sebagai periode window of opportunity.

Pendek di usia dewasa merupakan pencapaian pertumbuhan linier yang mempresentasikan adanya gangguan pertumbuhan dan perkembangan karena kekurangan gizi pada awal kehidupan. Sebagai suatu ukuran status gizi, pendek merefleksikan kekurangan gizi masa lalusebelum umur 2 tahun sebagai akibat dari hambatan pertumbuhan saat prenatal dan post natal (Martorell et al, 2002).

Berbagai studi pola pertumbuhan linier di Indonesia menunjukkan bahwa kegagalan pertumbuhan membawa konsekuensi adanya retained effect di usia selanjutnya. Berat dan panjang bayi yang sejak lahir sudah berada dibawah standar antropometri WHO akan tetap berada dibawah standar sampai umur 4 bulan dan akan tetap berada di bawah standar sampai usia 12 bulan (Kusharisupeni, 2013). Kegagalan pertumbuhan saat bayi dan anak-anak merupakan tolak ukur terjadinya kegagalan pertumbuhan dimasa selanjutnya (Simbolon, 2012).

Gambaran masalah pendek di Indonesia berdasarkan hasil Riskesdas menunjukkan bahwa balita pendek pada tahun 2007 sebanyak 36,8\% dan pada tahun 2010 sebanyak 35,7\%. Sedangkan prevalensi anak pendek untuk kelompok anak 6-12 tahun sebesar 35,6\%, kelompok umur 13-15 tahun sebesar 35,2\% dan pada kelompok umur 16-18 tahun sebesar 31,2\%. Data tersebut menunjukkan saat ini pendek merupakan problem utama kekurangan gizi dengan prevalensi cukup besar pada semua kelompok unsur dengan konsekuensi masalah kesehatan yang akan muncul di kemudian hari. Dengan asumsi tingkat kesejahteraan dan status gizi pada masa lalu yang tidak lebih baik dari sekarang, diperkirakan prevalensi pendek pada orang dewasa tidak berbeda jauh atau bahkan lebih tinggi (Mulyantoro, 2013).

Penderita diabetes mellitus di dunia saat ini diperkirakan lebih dari 346 juta orang. Jumlah ini akan meningkat lebih dari dua kali lipat pada 2030 jika tidak dilakukan intervensi. Menurut WHO (2011) bahwa hampir $80 \%$ dari kematian diabetes mellitus terjadi di negara berpenghasilan rendah dan menengah. Dalam beberapa tahun terakhir ini, penderita diabetes mellitus di Indonesia sudah banyak muncul tidak hanya di daerah perkotaan tetapi juga di daerah pedesaan. Analisis faktor risiko di DKI Jakarta menunjukkan bahwa kondisi sosial ekonomi tidak berhubungan dengan penyakit diabetes mellitus (Nurhayati, 2009).

Masalah kekurangan gizi di Indonesia pada periode perkembangan dan pertumbuhan sudah berlangsung lama dan sampai saat ini masih tetap menunjukkan tingginya prevalensi balita underweight dan wasting, serta pendek pada semua kelompok umur (Balitbang Kemenkes RI, 2010). Data Riskesdas 2010 menunjukkan bahwa berat lahir bayi kurang dari 3000 gram adalah sebesar 30,5\%. Bayi umur 1 bulan dengan berat lahir <3000 gram, sebesar 37,5\% mengalami stunting. Sedangkan bayi umur 2 bulan dengan berat lahir <3000 gram sebesar 40,3\% mengalami stunting .

Besarnya masalah pendek di usia dewasa yang merefleksikan kekurangan gizi diawal kehidupan dan kecenderungan peningkatan prevalensi penyakit diabetes mellitus di Indonesia, maka perlu dilakukan studi untuk mengetahui faktor resiko terhadap keduanya. Penelitian ini penting sebagai upaya preventif terhadap masalah yang masih dihadapi Indonesia saat ini yaitu kekurangan gizi pada wanita usia subur, ibu hamil dan balita yang cukup tinggi, karena tidak hanya pada penurunan intelektual yang akan mengakibatkan kurangnya produtifitas, tetapi juga risiko terkena diabetes mellitus yang akan mengakibatkan bebandalam pembiayaan kesehatan baik bagi individu, keluarga dan pemerintah. 


\section{METODE}

Penelitian ini bersifat kuantitatif, jenis analitik dengan desain studi kroseksional. Populasi penelitian adalah semua pasien yang menderita diabetes mellitus yang datang berobat ke RSUD Depok. Sampel adalah semua pasien diabetes mellitus yang berumur di atas 20 tahun, yang datang berobat ke poli penyakit dalam pada 26 September sampai 7 Oktober tahun 2016. Kriteria pasien diabetes mellitus ditentukan berdasarkan diagnosa dokter, sedangkan data berat badan, tinggi badan dan status ekonomi diperoleh secara primer melalui wawancara langsung dan pengukuran. Indeks massa tubuh ditentukan dengan cara membandingkan tinggi badan dan berat badan dengan rumus $\mathrm{BB}_{(\mathrm{kg})} / \mathrm{TB}^{2}{ }_{(\text {meter) }}$, kriteria kurus jika $<18,5$, normal jika $\geq 18,5-22,9$ dan kegemukan/ obesitas jika $\geq 23$ (WHO, 2004). Adapun stunting atau keadaan pendek ditentukan berdasarkan standar WHO 2006 dengan kriteria: pendek laki-laki jika $\mathrm{TB}<162 \mathrm{~cm}$, perempuan jika $\mathrm{TB}<150,1 \mathrm{~cm}$; normal laki-laki jika $\mathrm{TB} \geq 162 \mathrm{~cm}$, perempuan jika $\mathrm{TB} \geq 150,1 \mathrm{~cm}$. Jumlah sampel adalah sebanyak 60 responden, diambil secara purposive dengan teknik accidental sampling.

\section{HASIL}

Tabel 1. Gambaran Rata-rata Berat badan, Tinggi Badan dan Umur Responden

\begin{tabular}{lcrrrrr}
\hline Variabel & n & Mean & Med & SD & SE & $\begin{array}{c}\text { Min- } \\
\text { Maks }\end{array}$ \\
\hline $\begin{array}{l}\text { Berat } \\
\text { badan }\end{array}$ & 60 & 63,39 & 63,00 & 11,50 & 1,15 & $38-88$ \\
$\begin{array}{l}\text { Tinggi } \\
\text { badan }\end{array}$ & 60 & 158,31 & 157,50 & 9,5 & 0,95 & $144-180$ \\
Umur & 60 & 57,58 & 56,50 & 10,09 & 1,00 & $23-85$ \\
\hline
\end{tabular}

Tabel 2. Karakteristik Responden

\begin{tabular}{lcc}
\hline \multicolumn{1}{c}{ Karakteristik } & n & \% \\
\hline Stunting & & \\
\hline Pendek & 21 & 35 \\
Normal & 39 & 65 \\
\hline Jenis kelamin & & \\
\hline Laki-laki & 23 & 38 \\
Perempuan & 37 & 62 \\
\hline Umur & & \\
\hline$\leq 56,50$ & 31 & 52 \\
$>$ 56,50 & 29 & 48 \\
\hline IMT & & \\
\hline Kurus & 7 & 12 \\
Normal & 13 & 22 \\
Kegemukan/ Obesitas & 40 & 66 \\
\hline Status Ekonomi & & \\
\hline Kurang & 30 & 50 \\
Sedang & 20 & 33 \\
Tinggi & 10 & 17 \\
\hline
\end{tabular}

Tabel 3. Hubungan Stunting Diabetes mellitus dengan Jenis kelamin, Umur, IMT dan Status Ekonomi

\begin{tabular}{|c|c|c|c|c|c|c|c|c|}
\hline \multirow{3}{*}{ Variabel } & \multirow{2}{*}{\multicolumn{2}{|c|}{$\begin{array}{l}\text { Stunting } \\
\mathbf{Y a}\end{array}$}} & \multirow{2}{*}{\multicolumn{2}{|c|}{$\begin{array}{l}\text { DM } \\
\text { Tidak }\end{array}$}} & & & \multirow{3}{*}{$\begin{array}{c}\text { OR } \\
(95 \% \\
\text { CI }) \\
\end{array}$} & \multirow{3}{*}{$\begin{array}{c}p- \\
\text { value }\end{array}$} \\
\hline & & & & & \multicolumn{2}{|c|}{ Total } & & \\
\hline & $\mathbf{n}$ & $\%$ & $\mathbf{n}$ & $\%$ & $\mathrm{n}$ & $\%$ & & \\
\hline \multicolumn{9}{|c|}{ Jenis Kelamin } \\
\hline Laki-laki & 6 & 26,1 & 17 & 73,9 & 23 & 100 & \multirow{2}{*}{$\begin{array}{r}0,17- \\
1,62\end{array}$} & \multirow[t]{2}{*}{0,28} \\
\hline Perempuan & 15 & 40,5 & 22 & 59,5 & 37 & 100 & & \\
\hline \multicolumn{9}{|l|}{ Umur } \\
\hline$\leq 56,50$ & 15 & 48,4 & 16 & 51,6 & 31 & 100 & $1,15-$ & \multirow{2}{*}{0,03} \\
\hline$>56,50$ & 6 & 20,7 & 23 & 79,3 & 29 & 100 & 11,25 & \\
\hline \multicolumn{9}{|l|}{ IMT } \\
\hline Kurus & 3 & 42,9 & 4 & 57,1 & 7 & 100 & & \multirow{3}{*}{0,83} \\
\hline Normal & 5 & 38,5 & 8 & 61,5 & 13 & 100 & & \\
\hline $\begin{array}{l}\text { Kegemukan } \\
\text { sp. obesitas }\end{array}$ & 13 & 32,5 & 27 & 67,5 & 40 & 100 & & \\
\hline \multicolumn{9}{|c|}{ Status Ekonomi } \\
\hline Kurang & 12 & 40 & 18 & 60 & 30 & 100 & & \multirow{3}{*}{0,52} \\
\hline Sedang & 7 & 35 & 13 & 65 & 20 & 100 & & \\
\hline Tinggi & 2 & 20 & 8 & 80 & 10 & 100 & & \\
\hline
\end{tabular}

\section{PEMBAHASAN}

Hasil penelitian menunjukkan bahwa rata-rata berat badan responden adalah 63,39, berat tertinggi $88 \mathrm{~kg}$ sedangkan berat terendah adalah $38 \mathrm{~kg}$. Rata-rata tinggi badan responden adalah 158,31, tertinggi adalah $180 \mathrm{~cm}$ dan terpendek $144 \mathrm{~cm}$. Rata rata umur responden adalah 57,58, umur tertua 85 tahun dan umur termuda adalah 23 tahun.

Mean adalah ukuran rata-rata yang merupakan hasil dari jumlah semua nilai pengukuran dibagi banyaknya pengukuran. Keuntungan nilai mean adalah mudah menghitungnya dan melibatkan seluruh data dalam perhitungan. Namun kelemahan dari nilai mean adalah sangat dipengaruhi oleh nilai ekstrim, baik ekstrim tinggi maupun rendah. Oleh karena itu pada kelompok data yang mempunyai nilai ekstrim atau distribusi data yang miring, mean tidak dapat mewakili rata-rata kumpulan nilai pengamatan (Rianti, 2016).

Selanjutnya nilai median merupakan nilai yang dipakai untuk menentukan cut of point umur responden, karena distribusi data mempunyai nilai ekstrim atau tidak normal. Artinya dikatakan responden berisiko jika umur responden $\leq 56,50$, sedangkan tidak jika $>56,50$. Median adalah nilai dimana setengah banyaknya pengamatan mempunyai nilai dibawahnya dan setengahnya lagi mempunyai nilai di atasnya. Penghitungan median hanya mempertimbangkan urutan nilai hasil pengukuran, beda besar antar nilai diabaikan, sehingga median tidak dipengaruhi oleh nilai ekstrim.

Hasil penelitian memperlihatkan bahwa prevalensi stunting pada pasien diabetes mellitus 
masih cukup tinggi yaitu sebesar $35 \%$. Prevalensi tersebut sama dengan gambaran masalah pendek di Indonesia berdasarkan hasil Riskesdas 2007 yang menunjukkan bahwa balita pendek sebanyak 36,8\% dan pada tahun 2010 sebanyak 35,7\%. Sedangkan prevalensi anak pendek untuk kelompok anak 6-12 tahun sebesar 35,6\%, kelompok umur 13-15 tahun sebesar 35,2\% dan pada kelompok umur 16-18 tahun sebesar 31,2\%. Data tersebut menunjukkan saat ini pendek merupakan problem utama kekurangan gizi.

Hasil penelitian ini juga menunjukkan bahwa prevalensi stunting pada pasien diabetes mellitus sebagian besar terjadi pada perempuan yaitu sebesar $62 \%$. Dan prevalensi stunting pada pasien diabetes mellitus lebih banyak terjadi pada umur $\leq 56,50$ yaitu sebesar $52 \%$.

Berdasarkan IMT, hasil analisis menunjukkan bahwa prevalensi stunting pada pasien diabetes mellitus sebagian kecil terjadi pada responden yang kurus yaitu sebesar $12 \%$, sedangkan sebagian besar terjadi pada responden yang mengalami kegemukan yaitu sebesar $66 \%$. Tinggi badan merupakan salah satu ukuran antropometrik yang digunakan sebagai denumerator pada perhitungan indeks massa tubuh (IMT) yang mempengaruhi hasil penelitian status gizi. Pada keadaan berat badan yang sama tetapi tinggi badan lebih rendah akan memberikan hasil perhitungan IMT yang lebih tinggi. Dengan demikian pendek sebagai ukuran tinggi badan di bawah normal akan cenderung mempunyai nilai IMT lebih tinggi. Sehingga seseorang yang pendek cenderung lebih mudah mengalami kelebihan berat dibandingkan orang yang lebih tinggi.

Berdasarkan status ekonomi sebagian besar responden stunting diabetes mellitus mempunyai ekonomi yang kurang yaitu sebesar 50\%, diikuti ekonomi sedang 35\% dan ekonomi tinggi $20 \%$.

Tabel 3, hasil analisis bivariat menggunakan uji Fisher's Exact, menunjukkan bahwa tidak ada hubungan yang signifikan antara jenis kelamin dengan stunting pada pasien diabetes mellitus $(p=0,28)$. Jenis kelamin merupakan variabel biologis yang menunjukkan adanya perbedaan fisik, fisiologis dan hormonal. Perbedaan jenis kelamin memberikan pengaruh yang berbeda terhadap tinggi badan seperti perbedaan waktu dimulainya masa growth spurt antara laki-laki dan perempuan.

Hasil analisis menunjukkan bahwa adanya hubungan yang signifikan antara umur dengan stunting pada pasien diabetes mellitus $(\mathrm{p}=0,03)$. Umur adalah variabel biologis yang tidak dapat diubah, namun distribusi dan hubungan antara umur dengan stunting pada pasien diabetes mellitus menunjukkan asumsi bahwa tingkat kesejahteraan dan status gizi pada masa sekarang yang tidak lebih baik dari sebelumnya, sehingga diperkirakan prevalensi pendek pada orang dewasa tidak berbeda jauh atau bahkan lebih tinggi.

Hasil analisis menunjukkan bahwa tidak ada hubungan yang signifikan antara IMT dengan stunting pada pasien diabetes mellitus $(p=0,83)$. proporsi pendek semakin meningkat seiring dengan peningkatan nilai indeks massa tubuh. Menggunakan kategori IMT terlihat bahwa sebanyak $66 \%$ penderita stunting diabetes mellitus mengalami kelebihan berat badan sampai obesitas. Gambaran tersebut menunjukkan bahwa lebih dari setengah subyek yang pernah mengalami kekurangan gizi di awal kehidupan, sekarang menjadi kelebihan berat badan dan berisiko terkena penyakit tidak menular.

Hasil analisis menunjukkan bahwa tidak ada hubungan yang signifikan antara status ekonomi dengan stunting pada pasien diabetes mellitus $(p=0,52)$. Pendek merupakan keadaan status kesehatan yang berkaitan dengan hambatan pertumbuhan dan perkembangan saat janin dan 2 tahun pertama kehidupan, baik karena akibat kekurangan gizi dan atau penyakit infeksi. Efek jangka panjang yang masih terbawa sampai dewasa karena hambatan pertumbuhan selain pendek adalah penurunan kapasitas kognitif dan penurunan kapasitas kerja. Kapasitas kognitif dan kapasitas kerja yang rendah akan mengarah pada pencapaian tingkat ekonomi. Hasil penelitian Mulyantoro (2013) menunjukkan bahwa proporsi pendek semakin menurun seiring dengan peningkatan tingkat ekonomi keluarga. Pada penelitian ini memperlihatkan bahwa walaupun tidak terbukti secara statistik hubungan antara status ekonomi dengan stunting pada pasien diabetes mellitus namun kecenderungan bahwa sebagian besar responden mempunyai tingkat ekonomi rendah sampai sedang.

\section{SIMPULAN}

Studi ini menunjukkan adanya hubungan yang signifikan antara umur dengan stunting pada pasien diabetes mellitus. Walaupun secara biologis umur tidak dapat diubah, namun hubungan antara umur dengan stunting pada pasien diabetes mellitus menunjukkan asumsi bahwa tingkat kesejahteraan dan status gizi pada masa sekarang tidak lebih baik dari sebelumnya. Tidak terbukti ada hubungan yang bermakna antara jenis kelamin, IMT dan status ekonomi dengan stunting pada pasien diabetes mellitus. 


\section{SARAN}

Perlu penelitian lebih lanjut dengan desain yang lebih terkontrol untuk memastikan dampak jangka panjang terutama meningkatnya risiko terjadi berbagai penyakit tidak menular sebagai respon kekurangan gizi pada usia dini.

\section{DAFTAR PUSTAKA}

Badan Penelitian dan Pengembangan Kesehatan, Kementrian Kesehatan RI. 2010. Riset Kesehatan Dasar 2010.

Barker, D.J.P. 2008. Nutrition in the Womb, How Better Nutrition Development will Prevent Heart Disease, Diabetes and Stroke: The Development Origin of Health and Disease $(\mathrm{DOH} a \mathrm{D})$. The Barker Foundation.

Brown, L.S. 2011. Nutrition Requirements During Pregnancy. Essentials of Life Cycle Nutrition. Jones and Bartlett Publishers, LLC, 2011, USA.

Kusharisupeni. 2013. Gizi dalam Daur Kehidupan, dalam Gizi dan Kesehatan Masyarakat. Jakarta: PT Raja Grafindo Persada.

Martorell, R. et al. 2002. Stunting in Guatemala: Analyses of Change Over 15 Years. Agriculutural Policy Development Project. Research No.8 Abt Associates Inc.

Mulyantoro, K. D. 2013. Tinggi Badan Usia Dewasa dan Risiko Penyakit Diabetes Mellitus. Disertasi, Program Studi Doktor Ilmu Kesehatan Masyarakat, Fakultas Kesehatan Masyarakat UI.

Nurhayati S. et al. 2009. Gaya Hidup dan Status Gizi serta Hubungannya dengan Diabetes Mellitus pada Wanita Dewasa di DKI Jakarta. Gizi Indonesia, 32(2):117-127.

Rianti, E., 2016. Personal Higiene dalam Persfektif Islam. Doctoral Disertasi, Sekolah Pascasarjana UIN Syarif Hidayatullah Jakarta. https://scholar.google.co.id/citations?user= ME4xV4YAAAAJ\&hl=en

Simbolon, D. 2012. Model Prediksi Indeks Massa Tumbuh Remaja Berdasarkan Riwayat Lahir dan Status Gizi Anak, Studi Longitudinal The Indonesian Family Life Survey (IFLS) 1993-2007. Disertasi, Program Studi Doktor Ilmu Kesehatan Masyarakat, Fakultas Kesehatan Masyarakat UI.

World Health Organization. 2006. Diabetes Unit, Departemen of Chronic Disease and Health Promotion.

World Health Organization. 2011. Growth Reference Data for 5-19 years. 